\title{
Advanced Light Source Compendium of User Abstracts 2001
}

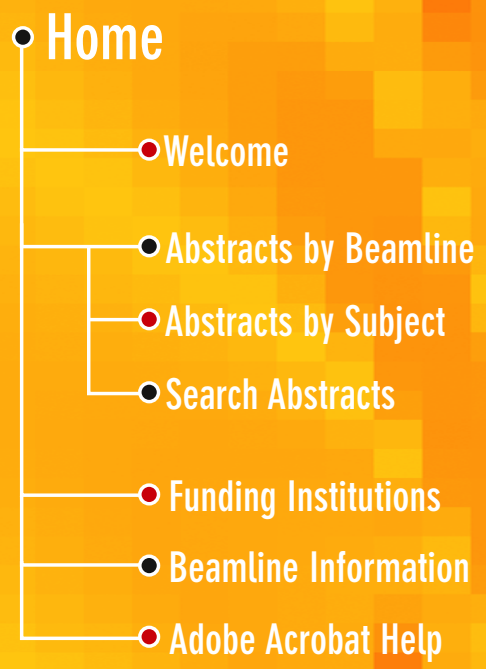

